\title{
NANOMINERALS: A POTENTIAL SUBSTITUTE FOR ANTIBIOTICS IN GUT-ASSOCIATED PATHOGENIC INFECTIONS OF LIVESTOCK
}

\author{
D.T. PAL ${ }^{1 *}$, N. K. S. GOWDA ${ }^{1}$ AND D. K. DEY ${ }^{1}$ \\ ${ }^{1}$ ICAR-National Institute of Animal Nutrition and Physiology, Bangalore- 560 030, Karnataka, India
}

\begin{abstract}
Diseases of the gastrointestinal (GI) tract or the gut could be bacterial, viral, fungal and/or parasitic such as protozoal, helminth etc. Out of all these causes, the bacterial diseases associated with the gut are predominant. Bacterial diseases of the gut not only implicate the functions of the gut, but its effects get manifested through disturbances in other physiological functions of the body as well. The most pertinent approach to ameliorate the gut associated bacterial infection are the use of antibiotics. Besides use as therapeutics, antibiotics are also used as growth promoters in poultry, and sometimes in pigs. Sustained and indiscriminate use of antibiotics have resulted in development of microbial resistance to antibiotics, and give rise to 'super-bugs', which are practically unmanageable at times. Moreover, the antibiotic residues are found in foods of the animal origin like milk, meat and eggs which cause a serious public health concern. These caveats have challenged the research community to explore novel antimicrobial agents. Nano materials as antimicrobials complementary to antibiotics are highly promising. Besides being highly bioavailable, nanominerals also facilitate in promoting growth in livestock, and imparting antimicrobial and immunomodulatory effects. The important antibacterial mode of action of the nanominerals are disruption of membrane integrity and/or its potential, production of reactive oxygen species, depletion of ATP production, denaturation of cytoplasmic ribosome subunit and disruption of protein translation. Metals and metal oxides nanoparticles such as silver $(\mathrm{Ag})$, iron oxide $\left(\mathrm{Fe}_{3} \mathrm{O}_{4}\right)$, titanium oxide $\left(\mathrm{TiO}_{2}\right)$, copper oxide $(\mathrm{CuO})$, and zinc oxide $(\mathrm{ZnO})$ nanoparticles are predominantly known to impart antimicrobial activity.
\end{abstract}

Key words: Antimicrobials, Gut health, Livestock, Nano minerals

\section{Introduction}

Since the past two decades, worldwide extensive research on both human and animal health revealed that the population of gut microbiome and their activity in the gut are responsible for the overall health and well-being of the host. A proper gut health is an indicator of good animal production (Kogut and Arsenault, 2016). Gut health includes several positive aspects of the gastrointestinal (GI) tract, such as the effective digestion and absorption of food, the absence of GI illness, normal and stable intestinal microbiota, effective immune status and a state of well-being. The GI barrier which lies in close proximity to the GI microbiota is an important aspect in understanding the complex mechanisms that maintain gut health. An impairment in the GI barrier can increase the risk of developing infectious, inflammatory and functional GI diseases, as well as extraintestinal diseases such as immune-mediated and metabolic disorders. Actually, gut health comprises a healthy upper and lower GI tract, although the term might suggest that it is majorly restricted to the lower GI tract wherein the microbiome or the gut microbes reside in abundance (Bischoff, 2011). Therefore, gut health can be defined as "a steady state where the microbiome and the intestinal tract exist in symbiotic equilibrium

\footnotetext{
*Corresponding Author
} 
and where the welfare and performance of the animal is not constrained by intestinal dysfunction" (Celi et al., 2017). Surprisingly, xenobiotic intervention rarely affects the host genome, however, the microbiome is readily affected by the changes in the diet, ingestion of antibiotics, and infection by pathogens, and other life events (Oakley et al., 2014).

The higher prevalence of the diseases associated with the GI tract is attributed to the fact that the gastrointestinal tract has the most extensive exposed surface in the body and is constantly exposed to a wide variety of potentially harmful substances (Yegani and Korver, 2008). Bacteria and protozoa, which include Salmonella, E. coli and Cryptosporidium etc., can negatively affect the GI barrier. A breach in the GI epithelial lining opens up multiple gateways for other bacteria, toxins, and pathogens causing the animal to be susceptible to diseases affecting multiple organs, and subsequently deteriorating the overall health status of the host animal. Improvised methods of amelioration of the digestive tract diseases in combination with proper feeding strategies can improve animal health beyond the gut (Hunt et al., 2002; Klein et al., 2008).

In order to ameliorate the gut associated pathogenic infestations and normalise the animal's health (particularly those caused by pathogenic bacteria), diverse broad-spectrum antibiotics have been in use since decades. Moreover, it has been a common practise to include sub-therapeutic doses of antibiotics in animal diets to promote growth of the animals owing to their ability to increase feed efficiency or prevent diseases, especially prevalent in the poultry industry (Kogut and Arsenault, 2016). Antibiotics have a profound effect on the normal microbiota of the host, thereby upsetting the ecological balance of the gut (Oakley et al., 2014). Deliberate and indiscriminate uses of antibiotics have resulted in development of multi-drug resistant population of bacteria. Thus, antimicrobial resistance poses a substantial global health concern and there is critical need for alternate therapeutic options to combat infections. The indiscriminate use of antimicrobials is resulting in escalated incidences of antibiotic resistance and triggering epidemics of hyper-virulent pathogens among livestock. Moreover, the transfer of antibiotic residue to humans as well as other animals through consumption of foods and food products of animal origin poses a significant public health concern for the consumers of milk, meat and eggs. In this regard, nano minerals have the future to be used as an alternative of antibiotic growth promoters to overcome the above problems. Contrary to prebiotics and probiotics which have competitive effect on pathogenic microbes in gut, nano minerals have the direct effect on pathogenic microbes for efficient management of gut health. Peters et al. (2016) reported about the vivid spectrum of application of nanotechnology as a tool in the fields of biology, biotechnology, mineral nutrition, physiology, reproduction and pharmacology in animals. Metal nanoparticles (NPs) are among the most promising of these because they exhibit a strong antibacterial activity.

\section{Antibacterial activity of metal and metal- oxide nanoparticles}

Antibacterial activity of metal and metal-oxide nanopar-ticles (NPs) has been extensively reported by Hemeg (2017). The size of the particles and the large surface area relative to volume of metal and metal oxide NPs enables intimate interactions with microbial membranes, as well as surface function which help in developing more effective antibacterial agents. Moreover, nanoparticles with antibacterial activities have the potential to reduce or eliminate the evolution of more resistant bacteria because nanoparticles target multiple species of bacteria at the same time, thereby averting the development of resistant strains. It also has the capability to overcome drug resistance due 
to their multi-functionality, as bacteria cannot develop multiple gene mutations simultaneously.

Over the last decade, there has been a remarkable focus globally on conventional as well as biogenic metallic nanoparticles as innovative tools for combating the high rates of antimicrobial resistance (Hemeg, 2017). In this regard, nanomaterials have shown promising results owing to their unique physical and chemical attributes (Pelgrift and Friedman, 2013; Beyth et al., 2015). Several studies have pointed out the antibacterial action of the metal nanoparticles (Theivasanthi and Alagar, 2011; Hajipour et al., 2012; Khurana et al., 2016; Sportelli et al., 2016; Patra and Baek, 2017).

\section{Mechanisms of antibacterial activity of metal and metal-oxide nanoparticles}

Several metal oxides in form of nanoparticles have been reported to exhibit marked antibacterial activity allowing efficient eradication of various bacterial strains. Each metal ion has its own sensitivity to different microorganisms (Ruddaraju et al., 2020). Nano particles can alter the metabolic activity of bacteria by maintaining contact with bacterial cells via electrostatic interaction, Van der Waals forces, receptor-ligand and hydrophobic interactions (Choi et al., 2017). Nano particles interact with the basic components of a bacterial cell causing oxidative stress, alterations in permeability and gene expression, disorders in electrolyte balance, protein deactivation and/or denaturation, and enzyme inhibition (Yang et al., 2009). Most of the current research proposes oxidative stress, metal ion release, and non-oxidative mechanisms as critical aspects of action of the nano minerals for manifestation of its bactericidal effects.

Both nanoparticles and metal ions are absorbed through the cell membrane of microbes. Once within a bacterial cell, the production of reactive oxygen species (ROS) such as hydroxyl radicals, superoxide anions and hydrogen peroxide in hibit DNA replication as well as amino acid synthesis. Moreover, it also damages the bacterial cell membranes via lipid peroxidation, compromising the membrane's semi permeability and repressing oxidative phosphorylation. $\mathrm{AgO}-$ and $\mathrm{ZnO}-$ nanoparticles have been reported to exert antibacterial activity by release of $\mathrm{Ag}$ ions and $\mathrm{Zn}$ ions that disrupt the membrane (Franci et al., 2015; Sirelkhatim et al., 2015; Dakal et al., 2016; Duran et al., 2016). Free $\mathrm{Cu}$ ions from $\mathrm{Cu}$-containing nanoparticles and $\mathrm{Mg}$ nanoparticles also induce formation of ROS (Hemeg, 2017). The antibacterial action of Ag-nanoparticle is revealed by interaction of $\mathrm{Ag}$ ions with sulfhydryl groups in enzymes and other cellular constituents, making the latter dysfunctional. Ag ions also preclude cell wall synthesis in Gram-positive bacteria. $\mathrm{Cu}$ ions interact with amine and carboxyl groups on the surfaces of microbial cells, such as Bacillus subtilis. Au-nanominerals also result in bacterial membrane disruption (Yoon et al., 2007). Inhibition of DNA replication and DNA degradation has also been reported with Cu-nanoparticles (Yoon et al., 2007; Chatterjee et al., 2014). Adsorption of nanominerals to bacterial cell is toxic to latter; with the positively charged nanoparticles being more toxic, which has been observed with $\mathrm{TiO}_{2}$ and surface-modified Aunanominerals (Wong et al., 2015; Shamaila et al., 2016). The Ag- and $\mathrm{ZnO}$-nanoparticles also results in damage to membrane lipids and proteins of bacterial cell surface (Sirelkhatim et al., 2015; Dakal et al., 2016; Duran et al., 2016). Ag ions inhibit cytochromes of the electron transport chain, and disrupt cellular transport systems (Pelgrift and Friedrman, 2013). Loss of membrane potential and disruption of respiratory chain has also been observed with $\mathrm{Au}, \mathrm{Cu}$ and $\mathrm{NiO}$ nanoparticles (Chatterjee et al., 2014; Khashan et al., 2016; Shamaila et al., 2016). Nanominerals also affect the internalization and subcellular localization, resulting in toxicity. In the cytoplasm, 
nanominerals exert microbicidal effects via oxidative stress and denaturation of the $30 \mathrm{~S}$ ribosomal subunit, thereby impeding protein translation (Rai et al., 2012; Duran et al., 2016; Shamaila et al., 2016). Furthermore, several researchers have reported that nanominerals comprising of $\mathrm{Ag}, \mathrm{Se}, \mathrm{ZnO}, \mathrm{TiO}_{2}, \mathrm{Cd}, \mathrm{Mg}$ and Bi can disrupt bacterial biofilms. (HernandezDelgadillo et al., 2012; Lellouche et al., 2012; Lee et al., 2014; Dakal et al., 2016; Duran et al., 2016; Guisbiers et al., 2016). In a pictorial summary, the following anti-bacterial mechanisms occur through the application of nanominerals (Fig.1)

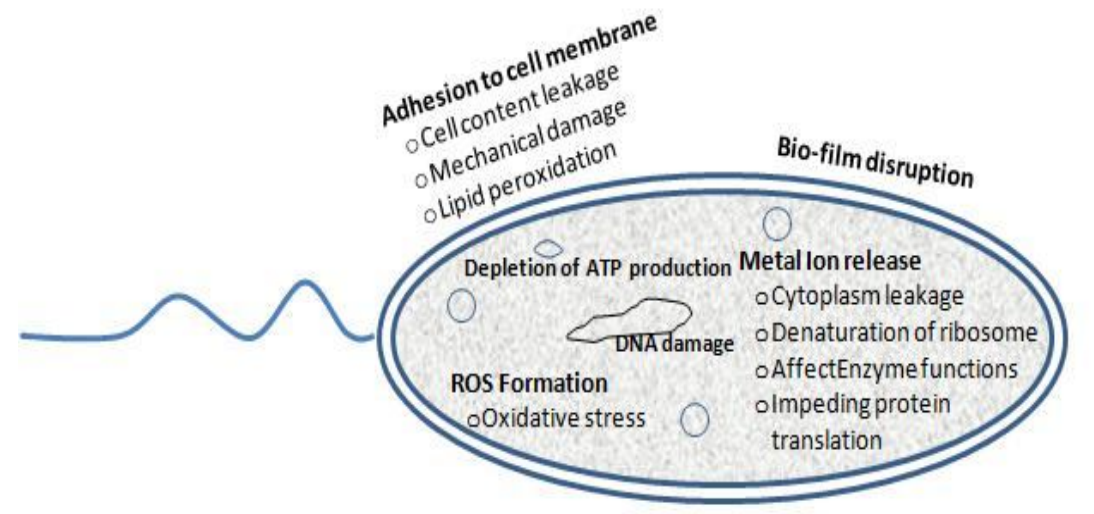

Fig. 1. Antimicrobial mechanisms of nanominerals

\section{Copper nanoparticles as anti-microbial agent in gut health}

In recent years, many studies have reported copper nanoparticles (Cu-NP) as a promising alternative to antibacterial reagents and a growth promoter. The use of Cunanoparticles has recently gained momentum due to their high electrical and melting points, low electrochemical migration behaviour, high bioavailability and relatively low cost of production (Tamilvanan et al., 2014). Cu-NP, because of their high physical reactivity, could be used as an alternative for an effective health and growth promoter in much smaller doses than bulk minerals in animal feed (GonzalesEguia et al., 2009; Joshua et al., 2016; Scott et al., 2016), thereby significantly reducing the excretion of these minerals into the environment. Moreover, Camacho-Flores et al. (2015) reported Cu-NPs to be an effective antibacterial, antifungal and antiviral agent. Although the mechanism of action as an antibacterial agent has still not been explicitly described, reports have suggested that the mechanism of antibacterial activity of $\mathrm{Cu}-\mathrm{NP}$ could be the same as that of silver nanoparticles (Rakhmetova et al., 2010; Rajendran et al., 2013). The antibacterial activity of $\mathrm{Cu}-\mathrm{NP}$ depends on the physical characteristics of the nanomaterial. The size of the $\mathrm{Cu}-\mathrm{NP}$ affects its toxicity by rapid and profound cellular uptake and translocation of the particles in the animal's body (Gatoo et al., 2014). On the similar aspect,

Civardi et al. (2015) have reported that the small size of the Cu-NP can increase its uptake from the GI tract, hence, making them more effective than the bulk $\mathrm{Cu}$ mineral, even at lower doses.

The inorganic copper salts used for synthesis of nanoparticles highly affect the antimicrobial property of nanominerals. The crystalline $\mathrm{Cu}-\mathrm{NP}$ has strong antimicrobial activity against both Gram-positive and Gram-negative bacteria (Scott et al., 2018). The different shape, size and strong antimicrobial activity of $\mathrm{Cu}-\mathrm{NP}$ have higher prospective in the field of biomedical sciences and food packaging (Shankar and Rhim, 2014). Copper nanoparticles due to their larger surface area are more effective antimicrobials as compared to organic and inorganic materials used in livestock health 
(Zaboli et al., 2013). It has been reported that the copper nanoparticle less than $100 \mathrm{~nm}$ size can enter into the blood stream through GI tract, and then enter into various organs and tissues. In poultry, it has been attributed to enhancing the immunity by influencing the gut microbiota (Wang et al., 2011; Thulasi et al., 2013). The linoleic acid-capped $\mathrm{Cu}-$ NP have immense bactericidal action for $S$. aureus, E. coli and Bacillus subtilis, suggesting that $\mathrm{Cu}-\mathrm{NP}$ can be used as effective growth inhibitors against various microorganisms (Das et al., 2010), making them applicable in improving gut health in livestock. Rajasekaran and Santra (2015) demonstrated that the chitosan implanted with $\mathrm{Cu}-\mathrm{NP}$ reduce gut bacteria such as E. coli, Enterococcus faecalis, S. Aureus and particularly, Lactobacillus fermentum, which could be used to minimise undesirable levels of microbial populations. The mechanism may be due to the dissipation of the cell membrane under the influence of nanoparticle accumulation or the generation of ROS by highly concentrated $\mathrm{Cu}^{2+}$ ions (Chatterjee et al., 2014). Ramyadevi et al. (2012) reported that the $\mathrm{Cu}-\mathrm{NP}$ is more toxic to bacteria than fungi. Moreover, the interactions of $\mathrm{Cu}-\mathrm{NP}$ with the immune system are a key issue to guide the future use of $\mathrm{Cu}-\mathrm{NP}$ in animal feed and medicine.

\section{Zinc nanoparticles as anti-microbial agent in gut health}

The importance of $\mathrm{Zn}$ in the animal system is well realised and explicitly documented. Nano$\mathrm{Zn}$ as a substitute to the conventional $\mathrm{Zn}$ sources can be a good alternative in livestock feeding. Apart from being highly bioavailable, reports have pointed out the growth promoting, antibacterial, immunomodulatory and many other beneficial effects of nano-Zn. Among metal nano particles, nano-zinc is the third highest globally produced nanometal after nano- $\mathrm{SiO}_{2}$ and nano- $\mathrm{TiO}_{2}$ (Piccinno et al., 2012). The sudden rise in the demand in zinc oxide nanoparticles ( $\mathrm{ZnO}-\mathrm{NP}$ ) is mostly attributed to its better antibacterial properties than the conventional $\mathrm{ZnO}$ (Padmavathy and Vijayaraghavan, 2008). ZnONP were shown to have a wide range of antimicrobial activity against various microorganisms (Palanikumar et al., 2014). Studies have already proved the dose dependant effect of $\mathrm{ZnO}-\mathrm{NP}$ as antimicrobial and immunomodulatory agent by reducing the diarrhoea rate in piglets (Hongfu, 2008). It has been observed that the health status and immunity of the birds by supplementing nano$\mathrm{Zn}$ to broiler diets at $0.06 \mathrm{mg} / \mathrm{kg}$ has improved significantly, as compared with the conventional dose of $15 \mathrm{mg} / \mathrm{kg}$ of organic and inorganic $\mathrm{Zn}$ with the basal diet (Sahoo et al., 2014a,b). Further, Hongfu (2008) has reported that supplementing basal diets with $400 \mathrm{mg} / \mathrm{kg}$ $\mathrm{ZnO}-\mathrm{NP}$, diarrhoea rate was reduced up to $49.1 \%$ compared with $21.6 \%$ upon supplementation of $3,000 \mathrm{mg} / \mathrm{kg} \mathrm{ZnO}$. Hence, this establishes the fact that $\mathrm{ZnO}-\mathrm{NP}$ are immensely effective antibacterial agents even at a very low concentration, compared to the conventional $\mathrm{ZnO}$.

\section{Selenium nanoparticles as anti-microbial agent for gut health}

Selenium nanoparticles (Se-NP) have been reported to possess potent antibacterial activity (Hirai et al., 2010; Yip et al., 2014). Se-NP when fed to broilers at a dose rate of $0.3 \mathrm{ppm}$ and $0.5 \mathrm{ppm}$ compared to both organic and inorganic selenium sources showed more efficacy and better performance in the treated group compared to control (Bagheri et al., 2015; Boostani et al., 2015; Selim et al., 2015). Se-NPs cross the membrane barriers of the bacteria imparting their antibacterial activity. Huang et al. (2016) reported that nanoselenium particle has efficient antibacterial and bactericidal activities, proving that these are good antimicrobial alternatives for the development of antimicrobial agents. Furthermore, they also stated that acetylcholine 
hybrids of Se-NP have the ability to combine with the acetylcholine receptor on the bacteria cell membrane and increase the permeability of cell membranes. This causes membrane disruption and leads to the leakage of the cytoplasm, allowing nanoparticles to subsequently invade bacterial cells and disrupt the DNA structure. Therefore, the acetylcholine-conjugated Se-nanoparticles have enhanced antibacterial activity. Quercetin and acetylcholine conjugated Se-nano particles significantly decrease the viability of $E$. coli and $S$. aureus cells over time. E. coli and S. Aureus when treated with $\mathrm{Se}$ - nanoparticles showed $60 \%$ reduction in the viability of both Grampositive and Gram-negative bacteria. This study results reveal a higher potency of antibacterial activities of quercetin and acetylcholine conjugated Se-nanoparticles. Besides this, the latter exhibit a synergistically enhanced antibacterial performance against the multi-drug resistant superbugs. Huang et al. (2016) reported that high antibacterial activity of Se-NPs is due to compromised bacterial cell membranes' integrity, by increased intracellular production of ROS, and/or disruption of the bacterial DNA structure upon entry into the cell. Se-NPs also restrain growth and biofilm formation of $E$. coli and S. Aureus (Guisbiers et al., 2016).

\section{Silver nanoparticles as anti-microbials for gut health}

Silver has a strong antimicrobial potential, and has been used since the ancient times. Silver in the form of various compounds and bhasmas (Ash) have been used in Ayurveda to treat several bacterial infections since time immemorial. With time, as several pathogenic bacteria are developing antibiotic resistance, silver nanoparticles are the new hope to combat them. Silver nanoparticles have been widely used as an effective antimicrobial agent against bacteria, fungi and viruses (Rai et al., 2009).

Although the mechanism of action of Ag-nanoparticle is still not clear,
Ag-nanoparticles of smaller diameter have a superior antimicrobial effect than those of their counterparts with larger diameter (Panacek et al., 2006). Silver ions are positively charged. This physical property of the Ag ion is crucial for its antimicrobial activity by virtue of the electrostatic interaction between negative charged cell membrane of microorganism and positive charged nanoparticles (Hamouda et al., 2000; Dibrov et al., 2002). Ag-nanoparticles increase the membrane permeability and inactivate the respiratory chain in Gram-negative bacteria like E. coli (Sondi and Salopek-Sondi, 2004; Beyth et al., 2010). Choi et al. (2008) revealed that the $\mathrm{Ag}$ ion which has an affinity for sulphur and nitrogen. This can inhibit and/or disrupt protein structure by binding to thiol and amino groups. Many earlier studies have further reported that silver nanominerals are photocatalytic and can induce production of ROS (Carlson et al., 2008; Piao et al., 2011; Ashok Kumar et al., 2014; Ninganagouda et al., 2014). Studies by Shahverdi et al. (2007) and Khurana et al. (2014) indicated that Ag-nanominerals also have synergistic antibacterial effects both on Gram-positive and Gram-negative bacteria when administered in combination with antibiotics. In yet another mechanism of antibacterial activity exhibited by Agnanoparticles is to bind to the thiol groups in enzymes, generating reactive oxygen species (ROS), and disrupting the conserved bacterial respiratory chain in different kinds of bacteria. In addition, Agions can also interact with microbial DNA, thereby inhibiting growth by obstructing DNA replication and cell division (Pineda et al., 2012; Dakal et al., 2016; Duran et al., 2016). Fondevila et al. (2009) have reported extensively about the antibacterial activity of silver nanoparticles in chickens and pigs. Besides demonstrating a significant antibacterial property, Gholami-Ahangaran et al. (2013) demonstrated that silver nanoparticles reduced the effects of aflatoxin 
on the growth and performance indices in broiler chickens suffering from experimental aflatoxicosis. While the supplementation of silver with a conventional diet had no effect on performance, however, the addition of silver nanoparticles to diet containing $3 \mathrm{ppm}$ aflatoxin significantly increased the cumulative bodyweight gain, cumulative feed consumption, and decreased the feed consumption ratio (FCR) in the last two weeks of the experimental period. The study, therefore concluded that supplement of silver nanoparticles to diet containing aflatoxin could diminish the inhibitory effects of aflatoxin. Chauke and Siebrits (2012) in one of their study replaced an antibiotic against coccidiosis with silver nanoparticles and found effective. The activities of the metal and metal oxide nanoparticles are summarised in the table 1 .

Table 1. Nano minerals and their effects on microbes

\begin{tabular}{|c|c|c|c|}
\hline $\begin{array}{l}\text { Metal } \\
\text { nano- } \\
\text { particles }\end{array}$ & Microbes affected & Effect on microbes & Reference \\
\hline $\mathrm{Cu}$ & $\begin{array}{l}\text { S. aureus, B. subtilis, } \\
\text { E. coli, Micrococcus } \\
\text { luteus, Klebsiella } \\
\text { pneumoniae and } \\
\text { Pseudomonas } \\
\text { aeruginosa }\end{array}$ & $\begin{array}{l}\text { Inhibits the growth, DNA replication, } \\
\text { induce membrane damage and } \\
\text { generation of ROS }\end{array}$ & $\begin{array}{l}\text { Fang et al., 2007; Raffi et } \\
\text { al., 2010; Applerot et al., } \\
\text { 2012; Pramanik et al., } \\
\text { 2012; Ramyadevi et al., } \\
\text { 2012; Shobha et al., } 2014\end{array}$ \\
\hline $\mathrm{Zn}$ & L. monocytogenes & Inhibits the growth and toxic to bacteria. & Arabi et al., 2012 \\
\hline $\mathrm{Zn}$ & Salmonella & Membrane disruption and ROS production & Jin et al., 2009 \\
\hline $\mathrm{Zn}$ & Klebsiella pneumonia & Membrane disruption and ROS production & Reddy et al., 2014 \\
\hline $\mathrm{Zn}$ & Streptococcus & Membrane disruption and ROS production & Kasraei et al., 2014 \\
\hline $\mathrm{Zn}$ & E. Coli & $\begin{array}{l}\text { Growth inhibition, damage bacterial cell } \\
\text { membrane, leakage of intracellular contents } \\
\text { and eventually the death of bacterial cells }\end{array}$ & $\begin{array}{l}\text { Liu et al., 2009; Liu et al., } \\
\text { 2009; Rajendran et al., } \\
2010\end{array}$ \\
\hline $\mathrm{Zn}$ & Staphylococcus aureus & Higher antibacterial effects & $\begin{array}{l}\text { Jones et al., 2008; } \\
\text { Rajendran et al., } 2010\end{array}$ \\
\hline $\mathrm{Zn}$ & P. aeruginosa & $\begin{array}{l}\text { Generation of ROS, disruption of membrane } \\
\text { permeability }\end{array}$ & Feris et al., 2010 \\
\hline $\mathrm{Zn}$ & Bacillus subtilis & $\begin{array}{l}\text { Electrostatic interactions, morphological } \\
\text { changes in the cell, increase in membrane } \\
\text { permeability }\end{array}$ & Sinha et al., 2011 \\
\hline $\mathrm{Se}$ & E. coli and S. aureus & $\begin{array}{l}\text { Inhibition of growth, directly kill bacteria } \\
\text { by changing cell permeability, attach to the } \\
\text { bacterial cell wall causing irreversible } \\
\text { damage to the membrane }\end{array}$ & $\begin{array}{l}\text { Hirai et al., 2010; Huang } \\
\text { et al., } 2016\end{array}$ \\
\hline $\mathrm{Se}$ & S. aureus & Inhibition of growth & Tran and Webster, 2011 \\
\hline $\mathrm{Ag}$ & $\begin{array}{l}\text { S. aureus and } \\
\text { Pseudomonas aeruginosa }\end{array}$ & $\begin{array}{l}\text { Generation of ROS, disrupting bacterial } \\
\text { respiratory chain }\end{array}$ & $\begin{array}{l}\text { Sondi and Salopek-Sondi, } \\
\text { 2004; Li et al., } 2005\end{array}$ \\
\hline $\mathrm{Fe}$ & Pseudomonas aeruginosa & Prevention of biofilm formation & Park et al., 2011 \\
\hline $\mathrm{Al}$ & E. coli & $\begin{array}{l}\text { Perforation and membrane disorganization, } \\
\text { leading to cell death }\end{array}$ & Ansari et al., 2014 \\
\hline $\mathrm{Mg}$ & E. coli and S. aureus & $\begin{array}{l}\text { Prevent biofilm formation, } \\
\text { inducing ROS, directly inhibit essential } \\
\text { enzymes of the bacteria }\end{array}$ & $\begin{array}{l}\text { Lellouche et al., 2009; } \\
\text { Blecher } \text { et al., } 2011\end{array}$ \\
\hline
\end{tabular}




\section{Nanominerals as growth-promoting agents}

Because of the 'nano' size and higher bioavailability, metal nanoparticles are also used as feed additives to enhance growth, performance and production in livestock. These also serve as a potent replacement of the antibiotic-based feed-additives which are used as growth promoters. Mishra et al. (2014) have reported that zinc oxide nanoparticles enhance growth performance, improve feed utility and provide economic benefits in weaning piglets and poultry. It has been found that in ruminants, large doses of $\mathrm{ZnO}$ nanoparticles cannot act as growth promoters, however, Hongfu (2008) has demonstrated that feeding a dose rate up to $3,000 \mathrm{mg} / \mathrm{kg}$ feed have proved to be promoting growth in pigs. In yet another experiment, chromium nanoparticles were fed to poultry at a dose rate of $500 \mathrm{mcg} / \mathrm{kg} \mathrm{Cr}^{3+}$. It not only affected the protein content of breast and thigh muscle positively; at the same time, it lowered the serum cholesterol levels too. It also improved average daily gain and feed efficiency of the broilers in the experimental group fed with chromium nanoparticles (Zha et al., 2009). Copper has been reported to be added as feed-additive in order to promote animal growth performance in addition to its antimicrobial properties (Solaiman et al., 2001; Zhao et. al., 2007). They have demonstrated that copper nanoparticles could improve piglet's energy and crude fat digestion through the augmentation of lipase and phospholipase A activity in the small intestine compared to a basal diet supplemented with $\mathrm{CuSO}_{4}$. These piglets also experienced an increase in daily weight gain, metabolic rates as well as immune capacity. Scott et al. (2018) suggested that $\mathrm{Cu}-\mathrm{NP}$ can allow more nutrients to be digested in the GIT, consequently improving the growth of chickens. In an experiment by Vijayakumar and Balakrishnan (2014), broiler birds fed with nano-form of calcium phosphate by replacing up to $50 \%$ requirement of dicalcium phosphate (DCP), showed a best feed conversion ratio of 1.39 $( \pm 0.02)$ and differed significantly from the control groups.

\section{Conclusion}

Nanotechnology thus confers an assurance as well as vast opportunity to attain specific target action by subtle modifications at a nano-scale. NPs are now being considered as a viable alternative to antibiotics due to their bactericidal, growth promoting and immunepotentiating properties. Metallic nanoparticles when used with the existing antibiotics for bacterial infections work synergistically by lowering the anti-biotics dosage to be administered, thereby minimizing toxicity as well as reducing the probability of development of resistance. Metal nanoparticles are advantageous over conventional systems of antibiotic therapy as they enhance therapeutic capacity by preventing microbial resistance. Further, metal nanoparticles have the capability to overcome drug resistance due to their multi-functionality, as bacteria cannot develop multiple gene mutations simultaneously. Apart from being highly bioavailable, using nanominerals as feed additives in livestock improve growth performance, and reduce the pathogen load to improve health and reduce the excretion of metals into the environment. Their small size and large surface-to-volume ratio make metal nanoparticles biologically more active than inorganic salts. Besides that, being highly bioavailable, these are required at a very low concentration compared to the conventional mineral salts, either as feed formulations or as therapeutics. Moreover, the most prominent and promising advantage is that there is no presence of antibiotic residues in foods of animal origin after using metal and/or metal oxide nanoparticles for antibacterial activity in the host animal. This fact is of stupendous significance when there is a global public 
health concern with regard to presence of antibiotic residues in food. Therefore, with the most concerning issue of microorganism resistance to antibiotics, developing new nanoparticles using metal ions or metal oxides

\section{REFERENCES}

Ansari MA, Khan HM, Khan AA, Cameotra SS, Saquib $\mathrm{Q}$ et al., 2014. Interaction of $\mathrm{Al}_{2} \mathrm{O}_{3}$ nano particles with Escherichia coli and their cell envelope biomolecules. J Appl Microbiol, 116(4): 772783, doi: $10.1111 /$ jam. 12423

Applerot G, Lellouche J, Lipovsky A, Nitzan Y, Lubart $\mathrm{R}$ et al., 2012. Understanding the antibacterial mechanism of $\mathrm{CuO}$ nanoparticles: revealing the route of induced oxidative stress. Small, 8(21): 3326-3337, doi: 10.1002/smll.201200772

Arabi F, Imandar M, Negahdary M, Imandar M, Noughabi MT et al., 2012. Investigation antibacterial effect of zinc oxide nanoparticles upon life of Listeria monocytogenes. Ann Biol Res, 3: $3679-3685$

Ashok Kumar D, Palanichamy V and Roopan SM, 2014. Photocatalytic action of $\mathrm{AgCl}$ nanoparticles and its antibacterial activity, J Photochem Photobiol, 138: 302-306, doi: 10.1016/j.jphotobiol.2014.06.011

Bagheri M, Golchin-Gelehdooni S, Mohamadi M and Tabidian A, 2015. Comparative effects of nano, mineral and organic selenium on growth performance, immunity responses and total antioxidant activity in broiler chickens. Int J Biol Pharm Allied Sci, 4(2): 583-595

Beyth N, Yudovin-Farber I, Perez-Davidi M, Domb AJ and Weiss EI, 2010. Polyethyleneimine nanoparticles incorporated into resin composite cause cell death and trigger biofilm stress in vivo. Proc Nat Acad Sci USA, 107(51): 22038-22043, doi: $10.1073 /$ pnas. 1010341107

Beyth N, Houri-Haddad Y, Domb A, Khan W and Hazan R, 2015. Alternative antimicrobial approach: nano-antimicrobial materials. Evid Based Complement Altern Med, 2015: 1-16, doi: $10.1155 / 2015 / 246012$

Bischoff SC, 2011. Gut health': A new objective in medicine? BMC med, 9(1): 24 is of great theoretical and practical concern to improve the gut health in livestock.

Conflict of interest: Authors do not have any conflict of interest

Blecher K, Nasir A and Friedman A, 2011. The growing role of nanotechnology in combating infectious disease. Virulence, 2(5): 395-401, doi: 10.4161/ viru.2.5.17035

Boostani A, Sadeghi AA, Mousavi SN, Chamani M and Kashan N, 2015. The effects of organic, inorganic, and nano-selenium on blood attributes in broiler chickens exposed to oxidative stress. Acta Sci Vet, 43: 1-6

Camacho-Flores BA, Martinez-Álvarez O, ArenasArrocena MC, Garcia-Contreras R, ArguetaFigueroa L et al., 2015. Copper: synthesis techniques in nanoscale and powerful application as an antimicrobial agent. J Nanomater, 2015: 415238, doi: 10.1155/2015/ 415238

Carlson C, Hussein SM, Schrand AM, Braydich-Stolle LK, Hess KL et al., 2008. Unique cellular interaction of silver nanoparticles: sizedependent generation of reactive oxygen species. J Phys Chem B, 112(43): 13608-13619, doi: $10.1021 /$ jp $712087 \mathrm{~m}$

Celi P, Cowieson AJ, Fru-Nji F, Steinert RE, Kluenter AM et al., 2017. Gastrointestinal functionality in animal nutrition and health: new opportunities for sustainable animal production. Anim Feed Sci Technol, 234: 88100, doi: 10.1016/j.anifeedsci. 2017.09.012

Chatterjee AK, Chakraborty R and Basu T, 2014. Mechanism of antibacterial activity of copper nanoparticles. Nanotechnol, 25(13): 135101, doi: 10.1088/0957-4484/25/13/135101

Chauke N and Siebrits FK, 2012. Evaluation of silver nanoparticles as a possible coccidiostat in broiler production. S Afr J Anim Sci, 42(5): 493 497, doi: 10.4314/sajas.v42i5.10

Choi O, Deng KK, Kim NJ, Ross Jr L, Surampalli RY et al., 2008. The inhibitory effects of silver nanoparticles, silver ions, and silver chloride 
colloids on microbial growth. Water Res, 42(12): 3066-3074, doi: 10.1016/j.watres.2008.02.021

Choi HJ, Pammi SVN, Park BJ, Eom JH, An H et al., 2017. Resistance against water and acid water $(\mathrm{pH}=4.0)$ via $\mathrm{Al}$-doped $\mathrm{ZnO}$ thin films for environmentally friendly glass panels. J Alloy Compd, 719: 271-280, doi: 10.1016/ j.jallcom.2017.05.190

Civardi C, Schubert M, Fey A, Wick P and Schwarze FWMR, 2015. Micronized copper wood preservatives: efficacy of ion, nano, and bulk copper against the brown rot fungus Rhodonia placenta. PLoS One, 10: e0142578, doi: 10.1371/journal.pone. 0142578

Dakal TC, Kumar A, Majumdar RS and Yadav V, 2016. Mechanistic basis of antimicrobial actions of silver nanoparticles. Front Microbiol, 7: 1831, doi: 10.3389/fmicb.2016.01831

Das R, Gang S, Nath SS and Bhattacharjee R, 2010. Linoleic acid capped copper nanoparticles for antibacterial activity. J Bionanosci, 4(1-2): 8286, doi: 10.1166/jbns.2010.1035

Dibrov P, Dzioba J, Gosink KK and Häse CC, 2002. Chemiosmotic mechanism of antimicrobial activity of $\mathrm{Ag}(+)$ in Vibrio cholerae. Antimicrob Agents Chemother, 46(8): 2668-2670, doi: 10.1128/AAC.46.8.2668-2670.2002

Duran N, Durán M, de Jesus MB, Seabra AB, Fávaro WJ et al., 2016. Silver nanoparticles: A new view on mechanistic aspects on antimicro-bial activity. Nanomed, 12(3): 789-799, doi: 10.1016/j.nano.2015.11.016

Fang J, Lyon DY, Wiesner MR, Dong J and Alvarez, 2007. Effect of a fullerene water suspension on bacterial phospholipids and membrane phase behaviour. Environ Sci Technol, 41(7): 26362642, doi: 10.1021/es062181w

Feris K, Otto C, Tinker J, Wingett D, Punnoose A et al., 2010. Electrostatic interactions affect nanoparticle-mediated toxicity to gram-negative bacterium Pseudomonas aeruginosa PAO1. Langmuir, 26(6): 4429-4436, doi: 10.1021/ la903491z

Fondevila M, Herrer R, Casallas MC, Abecia L and Ducha JJ, 2009. Silver nanoparticles as a potential antimicrobial additive for weaned pigs. Anim Feed Sci Technol, 150(3-4): 259269, doi: 10.1016/j.anifeedsci.2008.09.003
Franci G, Falanga A, Galdiero S, Palomba L, Rai M et al., 2015. Silver nanoparticles as potential antibacterial agents. Molecules, 20(5): 88568874, doi: $10.3390 /$ molecules20058856

Gatoo MA, Naseem S, Arfat MY, Mahmood Dar A, Qasim K et al., 2014. Physicochemical properties of nanomaterials: implication in associated toxic manifestations. Biomed Res Int, 2014: 1-8, doi: $10.1155 / 2014 / 498420$

Gholami-Ahangaran M and Zia-Jahromi N, 2013. Nanosilver effects on growth parameters in experimental aflatoxicosis in broiler chickens. Toxicol Ind Health, 29(2): 121-125, doi: $10.1177 / 0748233711425078$

Gonzales-Eguia A, Fu CM, Lu FY and Lien TF, 2009. Effects of nano copper on copper availability and nutrients digestibility, growth performance and serum traits of piglets. Livest Sci, 126(1-3): 122-129, doi: 10.1016/j.livsci.2009.06.009

Guisbiers G, Wang Q, Khachatryan E, Mimun L, Mendoza-Cruz R et al., 2016. Inhibition of E. coli and $S$. aureus with selenium nanoparticles synthesized by pulsed laser abla-tion in deionized water. Int J Nanomedicine, 11:37313736, doi: 10.2147 /IJN.S106289

Hajipour MJ, Fromm KM, Ashkarran AA, de Aberasturi DJ, de Larramendi IR et al. 2012. Antibacterial properties of nanoparticles. Trends Biotechnol, 30(10): 499-511, doi: 10.1016/j.tibtech. 2012.06.004

Hamouda T, Myc A, Donovan B, Shih AY, Reuter JD et al., 2000. A novel surfactant nano emulsion with a unique non-irritant topical antimicrobial activity against bacteria, enveloped viruses and fungi. Microbiol Res, 156(1): 1-7, doi: 10.1078/0944-5013-00069

Hemeg HA, 2017. Nanomaterials for alternative antibacterial therapy. Int $\mathrm{J}$ Nanomedicine, 12: 8211-8225, doi: 10.2147/IJN.S132163

Hernandez-Delgadillo R, Velasco-Arias, Diaz D, NiñoArevalo, Garza-Enriquez M et al., 2012. Zerovalent bismuth nanoparticles inhibit Streptococcus mutans growth and forma-tion of biofilm. Int J Nanomedicine, 7: 2109-2113, doi: 10.2147/IJN.S29854

Hirai I, Okuno M, Katsuma R, Arita N, Tachibana M et al., 2010. Characterisation of antiStaphylococcus aureus activity of quercetin. Int 
J Food Sci Technol, 45(6): 1250-1254, doi: 10.1111/j.1365-2621.2010.02267.x

Hongfu YBZ, 2008. Effects of nano-ZnO on growth performance and diarrhoea rate in weaning piglets. China Feed, 1: 008

Huang X, Chen X, Chen Q, Yu Q, Sun D et al., 2016. Investigation of functional selenium nanoparticles as potent antimicrobial agents against superbugs. Acta Biomater, 30: 397-407, doi: 10.1016/j.actbio.2015.10.041

Hunt E, Fu Q, Armstrong MU, Rennix DK, Webster DW et al., 2002. Oral bovine serum concentrate improves cryptosporidial enteritis in calves. Pediatr Res, 51(3): 370-376, doi: 10.1203/00006450200203000-00017

Jin T, Sun D, Su JY, Zhang H and Sue HJ, 2009. Antimicrobial efficacy of zinc oxide quantum dots against Listeria monocytogenes, and Salmonella enteritidis, Escherichia coli O157: H7. J Food Sci, 74: M46-M52, doi: 10.1111/ j. 1750-3841.2008. 01013.X

Jones N, Ray B, Ranjit KT and Manna AC, 2008. Antibacterial activity of $\mathrm{ZnO}$ nanoparticle suspensions on a broad spectrum of microorganisms. FEMS Microbiol Lett, 279(1): 71-76, doi: 10.1111/j.1574-6968.2007. 01012.x

Joshua PP, Valli C and Balakrishnan V, 2016. Effect of in ovo supplementation of nano forms of zinc, copper, and selenium on post-hatch performance of broiler chicken. Vet World, 9(3): 287-294, doi: 10.14202/vetworld. 2016.287-294

Kasraei S, Sami L, Hendi S, AliKhani MY, Rezaei-Soufi L et al., 2014. Antibacterial properties of composite resins incorporating silver and zinc oxide nanoparticles on Streptococcus mutans and Lactobacillus. Restor Dent Endod, 39(2): 109-114, doi: 10.5395/rde.2014.39.2.109

Khashan KS, Sulaiman GM, Abdul Ameer FA and Napolitano G, 2016. Syn-thesis, characterization and antibacterial activity of colloidal $\mathrm{NiO}$ nanoparticles. Pak J Pharm Sci, 29(2): 541-546

Khurana C, Vala AK, Andhariya N, Pandey OP and Chudasama B, 2014. Antibacterial activities of silver nanoparticles and antibiotic-adsorbed silver nanoparticles against bio recycling microbes. Environ Sci Process Impacts, 16(9): 2191-2198, doi: 10.1039/C4EM00248B
Khurana C, Vala AK, Andhariya N, Pandey OP and Chudasama B, 2016. Influence of antibiotic adsorption on biocidal activities of silver nanoparticles. IET Nanobiotechnol, 10(2): 6974, doi: 10.1049/iet-nbt.2015.0005

Klein P, Kleinová T, Volek Z and Šimùnek J, 2008. Effect of Cryptosporidium parvum infection on the absorptive capacity and paracellular permeability of the small intestine in neonatal calves. Vet Parasitol, 152 (1-2): 53-59

Kogut MH and Arsenault RJ, 2016. Gut health: The new paradigm in food animal production. Front Vet Sci, 3: 71, doi: 10.3389/fvets.2016.00071

Lee JH, Kim YG, Cho MH and Lee J, 2014. ZnO nanoparticles inhibit Pseudomonas aeruginosa biofilm formation and virulence factor pro-duction. Microbiol Res, 169(12): 888-896, doi: 10.1016/j.micres.2014.05.005

Lellouche J, Kahana E, Elias S, Gedanken A and Banin E, 2009. Antibiofilm activity of nanosized magnesium fluoride. Biomater, 30(30): 59695978, doi: 10.1016/j.biomaterials.2009.07.037

Lellouche J, Friedman A, Lahmi R, Gedanken A and Banin E, 2012. Antibiofilm surface functionalization of catheters by magnesium fluoride nanopar-ticles. Int J Nanomed, 7: 11751188, doi: 10.2147/IJN.S26770

Li P, Li J, Wu C, Wu Q and Li J, 2005. Synergistic antibacterial effects of B-lactam antibiotic combined with silver nanoparticles. Nanotech, 16 (9): 1912

Liu Y, He L, Mustapha A, Li H, Hu ZQ et al., 2009. Antibacterial activities of zinc oxide nanoparticles against Escherichia coli O157:H7. J Appl Microbiol, 107(4): 1193-1201, doi: 10.1111/j.1365-2672.2009. 04303.x

Mishra A, Swain RK, Mishra SK, Panda N and Sethy K, 2014. Growth performance and serum biochemical parameters as affected by nano zinc supplementation in layer chicks. Ind J Anim Nutr, 31(4): 384-388

Ninganagouda S, Rathod V, Singh D, Hiremath J, Singh AK et al., 2014. Growth kinetics and mechanistic action of reactive oxygen species released by silver nanoparticles from Aspergillus niger on Escherichia coli. Biomed Res Int, 2014: 53419, doi: 10.1155/2014/753419 
Oakley BB, Lillehoj HS, Kogut MH, Kim WK, Maurer $\mathrm{JJ}$ et al., 2014. The chicken gastrointestinal microbiome. FEMS Microbiol Lett, 360(2): 100-112, doi: 10.1111/1574-6968.12608

Padmavathy N and Vijayaraghavan R, 2008. Enhanced bioactivity of $\mathrm{ZnO}$ nanoparticles- An antimicrobial study. Sci Technol Adv Mater, 9(3):1-7, doi: 10.1088/1468-6996/9/3/035004

Palanikumar L, Ramasamy SN and Balachandran C, 2014. Size dependent antimicrobial response of zinc oxide nanoparticles. IET Nanobiotechnol, 8(2): 111-117, doi: 10.1049/iet-nbt.2012.0008

Panacek A, Kvitek L, Prucek R, Kolar M, Vecerova R et al., 2006. Silver colloid nanoparticles: synthesis, characterization, and their antibacterial activity. J Phys Chem, 110(33): 16248-16253, doi: 10.1021/jp063826h

Park H, Park HJ, Kim JA, SH Lee, JH Kim et al., 2011. Inactivation of Pseudomonas aeruginosa PA01 biofilms by hyperthermia using super paramagnetic nanoparticles. J Microbiol Methods, 84(1): 41-45, doi: 10.1016/ j.mimet.2010.10.010

Patra JK and Baek KH, 2017. Antibacterial activity and synergistic antibacterial potential of biosynthesized silver nanoparticles against foodborne pathogenic bacteria along with its anticandidal and antioxidant effects. Front Microbiol, 8: 167, doi: 10.3389/fmicb. 2017.00167

Pelgrift RY and Friedman AJ, 2013. Nanotechnology as a therapeutic tool to combat microbial resistance. Adv Drug Deliv Rev, 65(13-14): 18031815, doi: 10.1016/j.addr.2013.07.011

Peters RJB, Bouwmeester H, Gottardo S, Amenta V, Arena M et al., 2016. Nanomaterials for products and application in agriculture, feed and food. Trends Food Sci Technol, 54:155164, doi: 10.1016/j.tifs. 2016.06.008

Piao MJ, Kang KA, Lee IK, Kim SH, Kim S et al., 2011. Silver nanoparticles induce oxidative cell damage in human liver cells through inhibition of reduced glutathione and induction of mitochondria involved apoptosis, Toxicol Lett, 201(1): 92-100, doi: 10.1016/ j.toxlet.2010.12.010

Piccinno F, Gottschalk F, Seeger S and Nowack B,
2012. Industrial production quantities and uses of ten engineered nanomaterials for Europe and the world. J Nanopart Res, 14: 1109-1120, doi: 10.1007/s11051-012-1109-9

Pineda L, Chwalibog A, Sawosz E, Lauridsen C, Engberg R et al., 2012. Effect of silver nanoparticles on growth performance, metabolism and microbial profile of broiler, chickens. Arch Anim Nutr, 66(5): 416-429, doi: 10.1080/1745039X.2012.710081

Pramanik A, Laha D, Bhattacharya D, Pramanik P and Karmakar P, 2012. A novel study of antibacterial activity of copper iodide nanoparticle mediated by DNA and membrane damage. Colloids Surf B, 96: 50-55, doi: 10.1016/j.colsurfb. 2012.03.021

Raffi M, Mehrwan S, Bhatti TM, Akhter JI, Hameed A et al., 2010. Investigations into the antibacterial behaviour of copper nanoparticles against Escherichia coli. Ann Microbiol, 60: 75-80, doi: 10.1007/s13213-010-0015-6

Rai M, Yadav A and Gade A, 2009 Silver nanoparticles as a new generation of antimicrobials. Biotechnol Adv, 27(1): 76-83, doi: 10.1016/ j.biotechadv. 2008.09.002

Rai MK, Deshmukh SD, Ingle AP and Gade AK, 2012. Silver nanoparticles: The powerful nanoweapon against multidrug-resistant bacteria. J Appl Microbiol, 112(5): 841-852, doi: 10.1111/ j. 1365-2672.2012. 05253.x

Rajasekaran P and Santra S, 2015. Hydrothermally treated chitosan hydrogel loaded with copper and zinc particles as a potential micronutrientbased antimicrobial feed additive. Front Vet Sci, 2: 62, doi: 10.3389/fvets.2015.00062

Rajendran R, Balakumar C, Ahammed HAM, Jayakumar S, Vaideki K et al., 2010. Use of zinc oxide nanoparticles for production of antimicrobial textiles. Int J Eng Sci Technol, 2(1): 202-208

Rajendran D, Thulasi A, Jash S, Selvaraju S and Rao SBN, 2013. Synthesis and application of nano minerals in livestock industry. Animal Nutrition \& Reproductive Physiology (Recent Concepts). Sampath KT, Ghosh J, Bhatta R Eds., Satish Serial Publishing House, Delhi, pp517-530

Rakhmetova AA, Alekseeva TP, Bogoslovskaya OA, 
Leipunskii IO, Ol'khovskaya IP et al., 2010. Wound-healing properties of copper nanoparticles as a function of physicochemical parameters. Nantechnol Russ, 5: 271-276, doi: 10.1134/S199507801003016X

Ramyadevi J, Jeyasubramanian K, Marikani A, Rajakumar G and Rahuman AA, 2012. Synthesis and antimicrobial activity of copper nanoparticles. Mater Lett, 71: 114-116, doi: 10.1007/s11671-009-9264-3

Reddy LS, Nisha MM, Joice M and Shilpa PN, 2014. Antimicrobial activity of zinc oxide $(\mathrm{ZnO})$ nanoparticle against Klebsiella pneumonia. Pharm Biol, 52(11): 1388-1397, doi: 10.3109/ 13880209.2014.893001

Ruddaraju LK, Pammi SVN, Guntukuc GS, Padavalaa VS and Kolapalli VRM, 2020. A review on antibacterials to combat resistance: From ancient era of plants and metals to present and future perspectives of green nano technological combinations. Asian J Pharm Sci, 15(1): 42-59, doi: 10.1016/j.ajps.2019.03.002

Sahoo A, Swain RK and Mishra SK, 2014a. Effect of inorganic, organic and nano zinc supplemented diets on bioavailability and immunity status of broilers. Int J Adv Res, 2: 828-837

Sahoo A, Swain RK, Mishra SK and Jena B, 2014b. Serum biochemical indices of broiler birds fed on inorganic, organic and nano zinc supplemented diets. Int J Recent Sci Res, 5: 2078-2081

Scott A, Vadalasetty KP, Sawosz E, Łukasiewicz M, Vadalasetty RKP et al., 2016. Effect of copper nanoparticles and copper sulphate on metabolic rate and development of broiler embryos. Anim Feed Sci Technol, 220: 151-158, doi: 10.1016/ j.anifeedsci. 2016.08.009

Scott A, Vadalasetty KP, Chwalibog A and Sawosz E, 2018. Copper nanoparticles as an alternative feed additive in poultry diet: A review. Nanotechnol Rev, 7(1): 69-93, doi: 10.1515/ ntrev-2017-0159

Selim NA, Radwan NL, Youssef SF, Eldin TAS and Elwafa SA, 2015. Effect of inclusion inorganic, organic or nano selenium forms in broiler diets on: 1-growth performance, carcass and meat characteristics. Int J Poult Sci, 14(3): 135-143, doi: 10.3923/ijps.2015.135.143
Shahverdi AR, Fakhimi A, Shahverdi HR and Minaian S, 2007. Synthesis and effect of silver nanoparticles on the antibacterial activity of different antibiotics against Staphylococcus aureus and Escherichia coli. Nanomedicine, 3(2): 168-171, doi: 10.1016/j.nano.2007.02.001

Shamaila S, Zafar N, Riaz S, Sharif R, Nazir J et al., 2016. Gold nanoparticles: An efficient antimicrobial agent against enteric bacterial human pathogen. Nanomaterials (Basel), 6(4): 71, doi: 10.3390/nano6040071

Shankar S and Rhim JW, 2014. Effect of copper salts and reducing agents on characteristics and antimicrobial activity of copper nanoparticles. Mater Lett, 132: 307-311, doi: 10.1016/ j.matlet.2014.06.014

Shobha G, Moses V and Anand S, 2014. Biological synthesis of copper nanoparticles and its impactA review. Int J Pharm Sci Invent, 3(8): 28-38

Sinha R, Karan R, Sinha A and Khare SK, 2011. Interaction and nanotoxic effect of $\mathrm{ZnO}$ and $\mathrm{Ag}$ nanoparticles on mesophilic and halophilic bacterial cells. BioresourTechnol, 102(2): 15161520, doi: 10.1016/j.biortech.2010.07.117

Sirelkhatim A, Mahmud S, Seeni A, Kaus NHM, Ann LC et al., 2015. Review on zinc oxide nano-particles: antibacterial activity and toxicity mechanism. Nano-Micro Lett, 7(3): 219242, doi: 10.1007/s40820-015-0040-x

Solaiman SG, Maloney MA, Qureshi MA, Davis G and D'Andrea G, 2001. Effects of high copper supplements on performance, health, plasma copper and enzymes in goats. Small Ruminant Res, 41(2): 127-139, doi: 10.1016/s09214488(01)00213-9

Sondi and Salopek-Sondi B, 2004. Silver nanoparticles as antimicrobial agent: A case study on E. coli as a model for Gram negative bacteria, J Colloid Interface Sci, 275(1): 177182, doi: 10.1016/j.jcis. 2004.02.012

Sportelli MC, Picca RA, Ronco R, Bonerba E, Tantillo $\mathrm{G}$ et al., 2016. Investigation of industrial polyurethane foams modified with antimicrobial copper nanoparticles. Materials, 9(7): 544, doi: 10.3390/ma9070544

Tamilvanan A, Balamurugan K, Ponappa K and Madhan KB, 2014. Copper nanoparticles: 
synthetic strategies, properties and multifunctional application. Int J Nanosci, 13(2): 1430001, doi: 10.1142/S0219581X 14300016

Theivasanthi T and Alagar M, 2011. Studies of copper nanoparticles effects on micro-organisms. arXiv preprint arXiv: 1110.1372

Thulasi A, Rajendran D, Jash S, Selvaraju S, Jose VL et al., 2013. Nanobiotechnology of Animal Nutrition. Sampath, KT, Ghosh, J, Bhatta, R, Eds., Satish Serial Publishing House, New Delhi Chapter 24, pp499-516

Tran PA and Webster TJ, 2011. Selenium nanoparticles inhibit Staphylococcus aureus growth. Int J Nanomed, 6: 1553-1558, doi: 10.2147/ IJN.S21729

Vijayakumar MP and Balakrishnan V, 2014. Effect of calcium phosphate nanoparticles supplementation on growth performance of broiler chicken. Indian J Sci Technol, 7: 11491154, doi: 10.17485/ijst/2014/v7i8.20

Wang C, Wang MQ, Ye SS, Tao WJ and Du YJ, 2011. Effects of copper-loaded chitosan nanoparticles on growth and immunity in broilers. Poult Sci, 90(10): 2223-2228, doi: $10.3382 /$ ps.201101511

Wong MS, Chen CW, Hsieh CC, Hung SC, Sun DS et al., 2015. Antibacterial property of Ag nanoparticle-impregnated $\mathrm{N}$-doped titanium films under visible light. Sci Rep, 5: 11978, doi: $10.1038 /$ srep 11978

Yang W, Shen C, Ji Q, An H, Wang J et al., 2009. Food storage material silver nanoparticles interfere with DNA replication fidelity and bind with
DNA. Nanotechnol, 20(8): 085102, doi: 10.1088/ 0957-4484/20/8/085102

Yegani M and Korver DR, 2008. Factors affecting intestinal health in poultry. Poult Sci, 87(10): 2052-2063, doi: 10.3382/ps.2008-00091

Yip J, Liu L, Wong KH, Leung PHM, Yuen CWM et al., 2014. Investigation of antifungal and antibacterial effects of fabric padded with highly stable selenium nanoparticles. J Appl Polym Sci, 131(17), doi: 10.1002/app.40728

Yoon KY, Byeon JH, Park JH and Hwang J, 2007. Susceptibility constants of Escherichia coli and Bacillus subtilis to silver and copper nanoparticles. Sci Total Environ, 373(2-3): 572575, doi: 10.1016/j.scitotenv. 2006.11.007

Zaboli K, Aliarabi H, Bahari AA and Abbas AKR, 2013. Role of dietary nano-zinc oxide on growth performance and blood levels of mineral: A study on in Iranian Angora (Markhoz) goat kids. J Pharm Health Sci, 2(1): 19-26

Zha LY, Zeng JW, Chu XW, Mao LM, and Luo HJ, 2009. Efficacy of trivalent chromium on growth performance, carcass characteristics and tissue chromium in heat-stressed broiler chicks. J Sci Food Agric, 89(10): 1782-1786, doi: 10.1002/ jsfa. 3656

Zhao J, Harper AF, Estienne MJ, Webb Jr KE, McElroy AP et al., 2007. Growth performance and intestinal morphology responses in early weaned pigs to supplementation of antibiotic-free diets with an organic copper complex and spray-dried plasma protein in sanitary and non-sanitary environments. J Anim Sci, 85(5): 1302-1310, doi: $10.2527 /$ jas.2006-434 